\title{
Nuclear Factor NF-kappa-B p52 Subunit
}

National Cancer Institute

\section{Source}

National Cancer Institute. Nuclear Factor NF-kappa-B p52 Subunit. NCI Thesaurus. Code C129923.

Nuclear factor NF-kappa-B p52 subunit (454 aa, $\sim 49 \mathrm{kDa}$ ) is encoded by the human NFKB2 gene. This protein is involved in both transcriptional regulation and signal transduction. 